\title{
Design of Learning Media of Arabic Subject for Informatics Engineering Study Program
}

\author{
mabruroh $^{1}$, abdul hafidz zaid ${ }^{2}$, imam bahroni ${ }^{3}$ \\ \{mabruroh.gresik@gmail.com ${ }^{1}$, abuafadh@unida.gontor.ac.id ${ }^{2}$, masbahroni@gmail.com ${ }^{3}$ \} \\ ${ }^{1,2,3}$ University of Darussalam Gontor ${ }^{1},+6281338979121^{1}$, J1. Raya Siman No.6, Dusun I, Siman, \\ Kabupaten Ponorogo, East Java, Indonesia
}

\begin{abstract}
Learning media for reading is an influential element in the success of learning Arabic language for the college student level. Lecturers need to prepare the appropriate learning media to lead the success of reading learning. This study aims to produce printed learning media (books) of Arabic subjects that will be used in the college especially for students of Informatics Engineering, produce reading learning media, and formulate the effectiveness of teaching materials to improve students' reading skills based on a limited test. This study used Research and Development approach. In addition, this study employedtheoretical and practical analysis, the analysis of lecturer and student needs, design development, design validation, and limited design tests. The results of this study show that: (1) Design of reading learning media, and (2) the learning media is effective for reading class and independent learning. From the results of this study, it can be concluded that the printed learning media can be used in learning activities
\end{abstract}

Keywords: Arabic, Learning media, Textbook

\section{Introduction}

In the success of learning, appropriate and relevant learning media become one of the supporting factors. Learning media include lesson plans, research, media and methods that will be used in learning. In the learning process, assessment, media and methods that will be used in learning, lecturers must adjust all activities in learning with the conditions and abilities of students, especially in the preparation of learning media that serve as a support for learning success.[1] This is in line with the Regulation of Ministry of Education No. 56/2013 on the process standards, regulating the planning of the learning process and emphasizing that lecturers in the education unit must be able to develop lesson plans.

The success of learning is substantially influenced by the planning of learning media. One of the learning media is teaching material, which is in accordance with the learning objectives, abilities and fields taken by students. However, the availability of teaching materials that are in accordance with the learning objectives, abilities and fields taken by students are lack, even do not exist.[3] One of the cases in in Arabic course (reading) in the Department of Informatics Engineering at Darussalam University of Gontor..

Research on Arabic course learning media has been conducted and learning media has been produced to help the success of learning Arabic both in the printed and non-printed media. However, Arabic learning media for the realm of lectures at college get rarely paid attention to,especially in the Informatics Engineering study program which is in fact the subjects and terms learned use English and are difficult to find in Arabic, resulting in confusion in the learning process. 
From analysis, these problems come from the absence of Arabic learning media which causes a lack of enthusiasm from lecturers and students in carrying out learning activities. Therefore, this indicates that there are serious problems that must be immediately sought for a solution. In addition, it is feared that the absence of Arabic teaching materials that are in line with the Informatics Engineering study program will lead to the misachievement of competencies that have been set. If student's competence does not meet the standards set, it will not rule out the possibility of students not being able to compete in the national and international world.

Efforts in solving the arising problems in the learning process are the preparation of teaching materials in accordance with the learning objectives and the field pursued by students.[4] This study seeks to contribute knowledge and understanding of making appropriate teaching materials. Research conducted by the author in making teaching materials for students of Informatics Engineering study programs is feasible in terms of content, language, presentation and graphics.

Learning media used in teaching and learning activities can be printed or non-printed media. Printed learning media such as dictionaries, notebooks, textbooks, exercise books, and teacher's manuals.[5] While the learning media (books) created are lesson plans that are specifically intended to train students' skills and abilities in reading and understanding Arabic in the realm of Informatics Engineering which are in accordance with the age and generation of students equipped with vocabulary and exercises that will add insight and hone students' abilities.[6] Through this research, it is expected that it can foster interest in learning for students and related parties in developing learning activities.

Learning media are all materials (both information, tools, and texts) that are arranged systematically, which presents a complete figure of the competencies that will be mastered by students and used in the learning process with the aim of planning and studying learning implementation.[7] Teaching materials contain fields of study given to students in accordance with the objectives and learning curriculum, which are given by instructors to students to realize the desired learning objectives by paying attention to the affective, cognitive and psychomotor aspects.[8] In addition, there are four aspects that need to be considered in the preparation of teaching materials. These aspects include content or material, material presentation, language and readability, and graphic.[9]

This Arabic learning media (reading) is developed for the students of the $2^{\text {nd }}$ semester of Informatics Engineering study program at Darussalam University of Gontor and is adjusted to the students' level of ability in Arabic which is in the secondary level in learning Arabic. This textbook has several advantages, because there are principles and methods in learning. Each title is adapted to the Informatics Engineering course, supplemented with Arabic and vocabulary that explain the meaning of new and difficult words for students to understand, and there are also exercises that have a gradual difficulty level to hone Arabic language skills (reading) and in accordance with reading skills. It is arranged based on a design that can attract attention and arouse student learning enthusiasm, both in terms of shape, graphic arrangement, color, type and size of letters, and also with pictures as translator tools.

\section{Method}

This study used research and development method, aiming to create or develop products through trials of products.[10] This method was employed to produce certain products and test the effectiveness of the products. This research method was slightlymodified to be adjusted to the research context. The scope of the research was the development of Arabic teaching 
materials (reading) for students of Informatics Engineering study programs. In adjusting the research, ten stages were carried out, namely potential and problems, data collection, product design, design validation, design revisions, limited product trials, product revisions, product trials, product revisions, and mass production.[11]

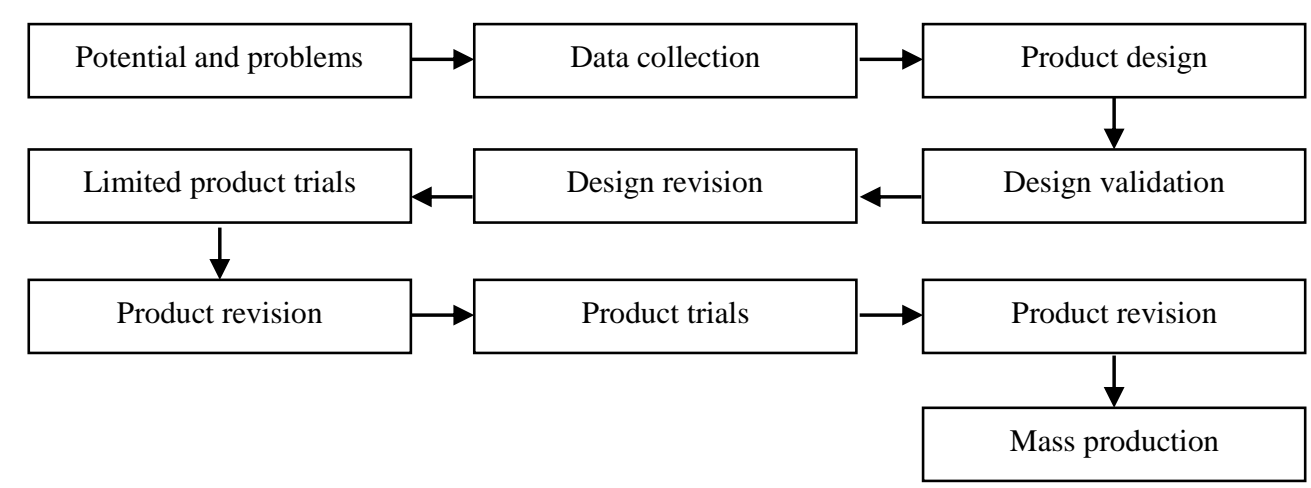

Fig. 1.Stages of Research \& Development

In the design validation stage, researchers asked for assistance from a team of experts, namely lecturers at the Department of Arabic Language Education and the Department of Informatics at the Darussalam University of Gontor. The expert team was divided into four fields, namely experts in learning, matrices, language, and graphic design. While the practitioner test team consisted of 2 people, and the number of user test samples included in this development study were 30 students. Analysis of the validation test results by experts used descriptive analysis method by calculating the percentage of experts' assessment, while the revision of the textbook was based on the results of discussions from the validation test by experts. Product revisions were based on results and evaluations on the first test and the results of the validation test. The first trial aimed to improve and revise the product, while the second trial aimed to determine the effectiveness of textbooks in improving Arabic language skills (reading). Analysis of the effectiveness of textbooks used the Paired Samples t-Test. Product revisions were carried out only if there is an evaluation of the results of the product usage test.[12]

\section{Result}

This study produced an Arabic textbook for reading skills to be the competence standard in learning Arabic, especially for students of Informatics Engineering study programs. This textbook consists of 100 pages including a calm presentation of Competency Standards, Basic Competencies and Achievement Indicators, allocation of learning time and instructions for using textbooks. This textbook is dominated by blue color and black writing on white paperto attract the attention of students and adapted to the realm of Informatics Engineering. This teaching material displays a lot of images with a good level of sharpness and bright color to make the readers do not get bored easily. The contents of the books that have been compiled and chapters on Arabic teaching materials (reading) for Informatics Engineering study programs are shown in Table 1. 
Table 1.Material contents of learning media

\begin{tabular}{ll}
\hline Chapter & \multicolumn{1}{c}{ Title } \\
\hline Chapter 1 & Minal 'Ulama' Al musliminfiiArriyadhiyaat \\
Chapter 2 & Asysyabakah Ad dauliyyah \\
Chapter 3 & Al hasub \\
Chapter 4 & MarahiluTathowwuratiTiknulujiya Al ma'lumat \\
Chapter 5 & MihanuTiknulujiya Al ma'lumat \\
Chapter 6 & Wasailu At tiknulujiya Al haditsahfiiKhidmati Ad da'wah \\
Chapter 7 & BarmajatulHasubi \\
Chapter 8 & Al fairusaat \\
Chapter 9 & ThuruquHimayati Al ma'lumat \\
Chapter 10 & Anwa'ulJaraimi Al iliktruniyyi \\
Chapter 11 & Iijabiyatu Al intirnit \\
Chapter 12 & Salabiyatu Al intirnit \\
\hline Chapter 13 & AadabuwaAkhlaqiyatuIstikhdami Al intirnit \\
Chapter 14 & KaifiyatuInsya'iMauqi'illiktruniy \\
\hline
\end{tabular}

The validity level of this textbook is shown in the results of validation test conducted by the experts stating that the initial design of this textbook of Arabic course (Reading) is Very Good with a percentage of $91.5 \%$. The full results are shown in the following table.

Table 2. Criteria of Product Validity

\begin{tabular}{|c|c|c|}
\hline No & Percentage & Level of product validity \\
\hline 1 & $0 \%-55 \%$ & Very Bad \\
\hline 2 & $56 \%-64 \%$ & Bad \\
\hline 3 & $65 \%-74 \%$ & Enough \\
\hline 4 & $75 \%-89 \%$ & Good \\
\hline 5 & $90 \%-100 \%$ & Very good \\
\hline
\end{tabular}

Based on the results of the assessment and evaluation of experts on the design of textbooks, product trials were conducted to determine the level of feasibility of Arabic textbooks (reading). The level of feasibility of textbooks is shown in the results of the trial of textbook products in a small scale learning, where researchers act as observers in the classroom by paying attention to the overall teaching and learning processes without being involved in it. From the questionnaire data involving the lecturers and students, the following descriptive analysis results are obtained (Tables 3 and 4).

Table 3. Recapitulation of Teacher Questionnaire Data on Product Feasibility

\begin{tabular}{|l|l|l|}
\hline No & Component & $\begin{array}{l}\text { Percenta } \\
\text { ge }\end{array}$ \\
\hline 1 & The role of textbooks in facilitating the teaching process & $80 \%$ \\
\hline 2 & Systematic preparation of textbooks & $80 \%$ \\
\hline 3 & The suitability of the material with the environment & $100 \%$ \\
\hline 4 & The suitability of language with the level of language & $100 \%$ \\
\hline
\end{tabular}




\begin{tabular}{|l|l|l|}
\hline & ability of learners & \\
\hline 5 & Textbook vocabulary & $80 \%$ \\
\hline 6 & Material in the textbook & $100 \%$ \\
\hline 7 & Exercise in the textbook & $80 \%$ \\
\hline 8 & Examples of sentence construction & $80 \%$ \\
\hline
\end{tabular}

From the results of descriptive analysis of teacher questionnaire data, it is known that Arabic textbook is good and feasible for writing skill with a percentage of $87,5 \%$.

Table 4. Recapitulation of Student Questionnaire Data on Product Feasibility

\begin{tabular}{|l|l|l|}
\hline No & Component & Percentage \\
\hline 1 & The suitability of textbooks with daily activities & $74 \%$ \\
\hline 2 & Simple language in the textbook & $74 \%$ \\
\hline 3 & Exercise in the textbook & $76 \%$ \\
\hline 4 & Simple sentences in the textbook & $77 \%$ \\
\hline 5 & Simple vocabularies in the textbook ajar & $79 \%$ \\
\hline 6 & Simple examples of sentence arrangements & $76 \%$ \\
\hline
\end{tabular}

From the results of descriptive analysis of student questionnaire data, it is known that Arabic textbook (reading) is good and eligible with a percentage of $76 \%$.

In the testing phase, the first trial provide exercise in Arabic language material (reading) before the textbook was used in the learning process, while the second trial was conducted after the textbook was in the learning process.From the trials, it can be seen that there were significant differences, i.e. the mean for pre-test (Y1) was 5.1 and for post-test (Y2) was 6.3; therefore, the difference was 1.2. Significant value differences indicate that this textbook is effective in helping improve Arabic language skills of the students of Informatics Engineering study programs, especially in reading skills.

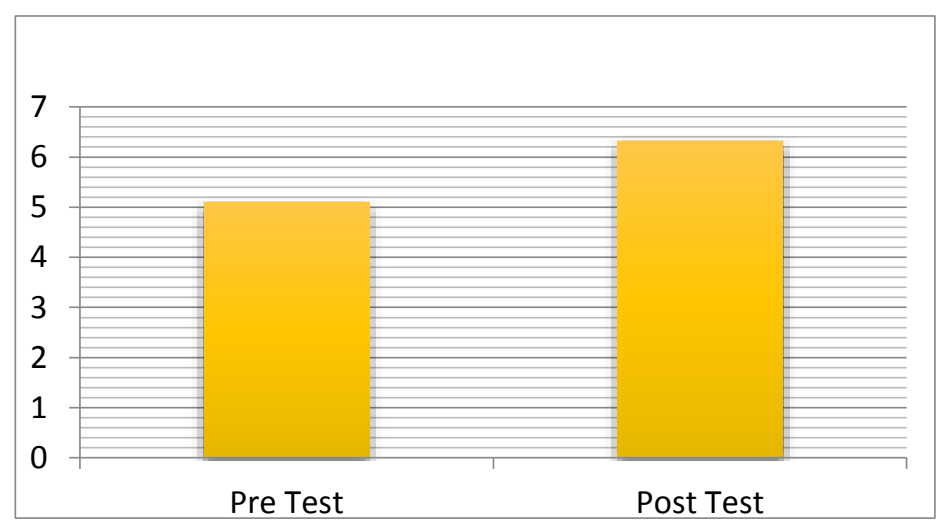

Fig. 2.Comparison of pretest and posttestscore 
The results of t-Test on paired samples with pre-test and post-test scores are shown with the following output:

Table 8. The results of t-Test on paired samples

Paired Samples Test

\begin{tabular}{|c|c|c|c|c|c|c|c|c|}
\hline & \multicolumn{5}{|c|}{ Paired Differences } & & \multirow{3}{*}{ df } & \multirow{3}{*}{$\begin{array}{l}\text { Sig. } \\
\text { tailed })\end{array}$} \\
\hline & \multirow[t]{2}{*}{ Mean } & \multirow[t]{2}{*}{$\begin{array}{l}\text { Std. } \\
\text { Deviation }\end{array}$} & \multirow{2}{*}{$\begin{array}{l}\text { Std. } \\
\text { Error } \\
\text { Mean }\end{array}$} & \multicolumn{2}{|c|}{$\begin{array}{ll}95 \% & \text { Confidence } \\
\text { Interval of the } \\
\text { Difference }\end{array}$} & & & \\
\hline & & & & Lower & Upper & & & \\
\hline Pair 1 Y1 - Y2 & $-1,20000$ & 1,15166 &, 25752 & $-1,73899$ &,- 66101 & $-4,660$ & 19 &, 000 \\
\hline
\end{tabular}

Hypothesis formulationsof t-test forpaired sample as follows: Ho: there is no difference between pre-test and post-test scores Ha: there is a difference between pre-test and post-test scores.

The test criteria in the $\mathrm{t}$-test for paired samples are if $\mathrm{t}$-count $\geq \mathrm{t}$-table or $\mathrm{t}$-count $\leq \mathrm{t}$-table, Ho is accepted, and if $\mathrm{t}$-count $<\mathrm{t}$-table or $\mathrm{t}$-count $>\mathrm{t}$ table, Ho is rejected . T-table value is a statistical table value at a significance of 0.05 with a degree of freedom df 19 , i.e. -1.72 . The output in Table 4 shows that the value of $t$-count $>t$-table $(-4.660>-1.72)$; thus, Ho is rejected and it can be concluded that there is a difference between the pre-test and post-test values.[13]

\section{Conclusions}

From the result of analysis, this Arabic textbook (reading) is good and feasible to be used in terms of content, language, presentation and graphics, because it has been through validation from experts and the feasibility and effectiveness tests. The effectiveness of this textbook can be seen from the significant difference between the pre-test and post-test average scores that have been carried out on a small scale. In addition, this textbook can help the second semester students of Informatics Engineering study programs in improving their Arabic language skills, especially in reading skills.

\section{Suggestions}

It is expected that lecturers of Arabic course will pay more attention to all language proficiency possessed by students, especially in the ability to read and determine appropriate teaching materials, because this is one of the skills that plays a major role in students to open the window of knowledge. This research and research product can be developed based on the needs of each campus and student. It is expected that this textbook can be used to achieve the objectives of this textbook, i.e. to help and develop Arabic language skills (reading), especially for students of Informatics Engineering. 


\section{Aknowledgment}

The author would like to thank the Ministry of Research, Technology and Higher Education which have supported research funding, and Darussalam University of Gontor which have facilitated various stages of research, both in data collection, data acquisition and also the preparation of research reports.

\section{References}

[1] A. Prastowo, No TitlePanduan Kreatif Membuat Bahan Ajar Inovatif:Menciptakan Metode Pembelajaran yang Menarik dan Menyenangkan. 2015.

[2] M. S. Sahrir and N. A. Alias, "A Design and Development Approach to Researching Online Arabic Vocabulary Games Learning in IIUM," Procedia - Soc. Behav. Sci., 2012.

[3] F. Alawi Fikri, “Improving students ability in writing descriptive text using clustering technique," J. English Lang. Teaching., 2011.

[4] A. F. Effendy, Metodologi Pengajaran Bahasa Arab. Malang: Misykat, 2005.

[5] Depdiknas, "DEPDIKNAS," in Panduan Pengembangan Bahan Ajar, 2008.

[6] A. Prastowo, "Panduan Kreatif Membuat Bahan Ajar Inovatif," PLoS Med., vol. 4, no. 6, pp. 1132-1133, 2014.

[7] R. B. Kozma, "Learning with Media," Rev. Educ. Res., 1991.

[8] A. H. Hernawan, Permasih, and L. Dewi, "Panduan Pengembangan Bahan Ajar," 2008.

[9] Mohd Fadzli Ismail and Mohd Sukki Othman, "Faktor-faktor yang mempengaruhi pencapaian pelajar dalam pengajaran \& pembelajaran bahasa Arab: Satu tinjauan di SMAP Kajang," Persidang. Kebangs. Pengajaran Dan Pembelajaran Bhs. Arab 2012, 2012.

[10] M. P. Caldas, "Research design: qualitative, quantitative, and mixed methods approaches," Rev. Adm. Contemp., 2003.

[11] J. W. Creswell, Educational research: Planning, conducting, and evaluating quantitative and qualitative research. 2012.

[12] Sugiyono, "Pendekatan Kuantitatif, Kualitatif, Kombinasi, R\&D dan Penelitian Evaluasi," in Metodelogi Penelitian, 2017.

[13] SPSS Inc, "SPSS Advanced Statistics 17.0," Statistics (Ber)., 2007. 